\title{
PENINGKATAN HASIL BELAJAR SISWA KELAS IV \\ MATA PELAJARAN BAHASA INDONESIA MATERI WAWANCARA DENGAN MODEL MAKE A MACTH DI SDN 5 OLEAN
}

Mory Victor Febrianto, M.Pd.I ${ }^{1}$

${ }^{1}$ FKIP, Universitas Abdurachman Saleh

\begin{abstract}
ABSTRAK
Berdasarkan observasi awal bahwa di SD Negeri 5 Olean kecamatan Situbondo Kabupaten Situbondo, ditemukan suatu permasalahan dalam pembelajaran Bahasa Indonesia. Hasil observasi yang menunjukkan bahwa dari hasil ulangan harian siswa, sebanyak 40\% dari 15 siswa di kelas IV yang berarti daya serap klasikal masih dibawah standar 70\% dari 15 siswa. Keadaan ini diperparah lagi dengan penggunaan metode pembelajaran ceramah dan penugasan yang dipakai guru pada saat kegiatan belajar mengajar berlangsung dan siswa menjadi pasif dan kurang berinteraktif sehingga nilai ulangan harian siswa menjadi rendah. Desain penelitian dalam penelitian ini adalah penelitian tindakan kelas. Berdasarkan hasil yang telah dilakukan dapat ditarik kesimpulan sebagai berikut: penerapan model pembelajaran Make A Matchdapat meningkatkan hasil belajar siswa mata pelajaranBahasa Indonesia materi wawancara mencapai $60 \%$ yang tuntas dan $40 \%$ yang tidak tuntas pada siklus I menjadi $86,67 \%$ yang tuntas dan $13,33 \%$ yang tidak tuntas pada siklus II di Kelas IV SD Negeri 5Olean Kecamatan Situbondo Kabupaten Situbondo.

Kata Kunci: Model Pembelajaran Make A Match, Wawancara, Hasil belajar
\end{abstract}

\begin{abstract}
Based on preliminary observations that at SD Negeri 5 Olean, Situbondo District, Situbondo District, a problem was found in learning Indonesian. The results of the observations showed that from the results of the students' daily tests, as many as $40 \%$ of the 15 students in grade IV, which means that classical absorption is still below the standard of $70 \%$ of 15 students. This situation is exacerbated by the use of lecture learning methods and assignments used by the teacher during teaching and learning activities and students become passive and less interactive so that the students' daily test scores are low. The research design in this research is classroom action research. Based on the results that have been done, the following conclusions can be drawn: the application of the Make A Match learning model can improve student learning outcomes in Indonesian subjects, the interview material reaches $60 \%$ complete and $40 \%$ incomplete in cycle I to $86.67 \%$ complete and $13,33 \%$ who did not complete the second cycle in Class IV SD Negeri 5Olean, Situbondo District, Situbondo Regency.
\end{abstract}


Keywords: Make A Match Learning Model, Interview, Learning Outcomes

\section{PENDAHULUAN}

Suatu proses pembelajaran dirancang sedemikian rupa untuk memberikan pengalaman belajar yang melibatkan proses mental dan fisik melalui interaksi antar siswa, siswa dengan guru, lingkungan dan sumber belajar lainnya dalam rangka pencapaian kompetensi dasar.

Dari prestasi belajar siswa menunjukkan bahwa tingkat penguasaan peserta didik terhadap tugas-tugas dalam kegiatan pembelajaran Bahasa Indonesia materi pokok Bahasa Indonesia rata-rata masih rendah. Siswa cenderung mengalami kesulitan ketika membuat daftar pertanyaan untuk wawancara serta melakukan kegiatan wawancara kepada narasumber.

Hasil belajar bahasa Indonesia Siswa kelas IV di SDN 5 Olean sebanyak $40 \%$ atau 6 siswa dari 15 siswa telah mencapai KKM yang telah disepakati di kelas IV di SDN 5 Olean yaitu 70, sedangkan sebanyak $60 \%$ atau 9siswa yang belum mencapai KKM.. Hal tersebut dapat disebabkan oleh beberapa faktor, diantaranya adalah kurangnya pengetahuan siswa terhadap materi wawancara. Pada umumnya permasalahan yang terjadi pada proses pembelajaran di kelas IV di SDN 5 Olean, guru menggunakan metode ceramah tanpa memberi contoh kalimat tanya yang sesuai dengan kalimat tanya. Siswa cenderung merasa malu untuk melakukan kegiatan wawancara terhadap narasumber. Secara individu siswa kesulitan melakukan kegiatan wawancara, mencatat hasil wawancara, menyimpulkan hasil wawancara, dan membuat laporan hasil wawancara.

Rendahnya perhatian siswa juga mempengaruhi hasil belajar siswa bahasa Indonesia.Pada model Make a Macth, siswa selain belajar materi juga belajar bagaimana dapat melakukan kegiatan bersama dengan teman-temannya, bagaimana bekerja dalam tim dan saling menghargai antara satu dengan lainnya.

Melalui Make a Macth pada pembelajaran bahasa Indonesia siswa dapat saling berkomunikasi dalam membuat daftar pertanyaan wawancara. Siswa juga dapat saling bekerja sama ketika melakukan kegiatan wawancara bersama narasumber dengan memperhatikan keterampilan wawancara.

\section{METODE PENELITIAN}

Penelitian ini menggunakan rancangan penelitian tindakan kelas (PTK). Hakikat tindakan kelas adalah adanya upaya tindakan yang dilakukan secara terencana dan sistematis untuk memecahkan masalah pembelajaran di kelas yang dihadapi oleh para guru sehari-hari 361 | JURNAL IKA VOL 8 No. 2 DESEMBER 2020 
menurut (Sunardi dalam Sukri 2010:15). (Sunardi dalam Sukri 2010:15) menyatakan bahwa model PTK berbentuk spiral dengan masing-masing siklus terdiri atas 4 tahap, yaitu perencanaan, tindakan, observasi, dan refleksi.

Keempat tahap tersebut dipandang sebagai siklus spiral dan dapat digambarkan sebagai berikut.

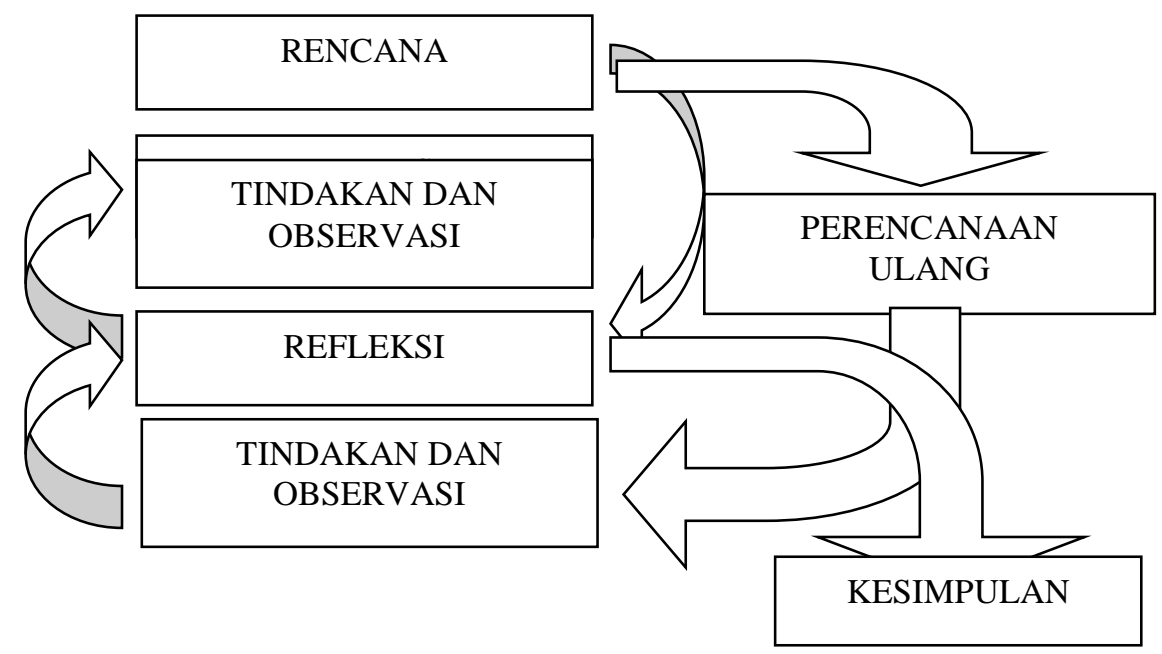

Gambar 3.1 Adaptasi dari model Kemmis \& Mc Taggart (dalam Sukri, 2010:15)

\section{Pelaksanaan Make a Match}

Langkah-langkah model pembelajaran Make a Match adalah sebagai berikut :

a. Guru membentuk kelompok dengan materi yangberbeda.

b. Guru menyiapkan kartu soal dan kartujawaban.

c. Guru menyiapkan 4 kotak/kardus. Dua untuk tempat soal dan dua untuk tempatjawaban.

d. Guru menyiapkan lagi dua kotak/kardus untuk tempat hasil pemasangan soal dan jawaban dari peserta lalu disiapkan pula papanskor/hasil.

e. Dilakukan pengundian untuk menentukan kelompok yang akan saling berhadapan. Kemudian dibuat baganpertandingan.

f. Sesuai undian maka 2 kelompok akan saling berhadapan dalamgame/kuis.

g. Dua orang dari masing-masing kelompok akan memasangkan soal dan jawaban dalam waktu yang telahditentukan.

h. Setelah aba-aba dibunyikan, maka pasangan dari dua kelompok ini berlomba adu cepat memasangkan soal dan jawaban dari 2 kotak yang telah disediakan.

i. Pasangan soal dan jawaban yang telah ditemukan, dimasukkan ke dalam kotak lain yang telahdisediakan. 
j. Bila waktu telah habis peserta berhenti. Pasangan soal dan jawaban yang ada di kotak dicocokan dan dihitung berapa pasang yang berhasildikumpulkan.

k. Pasangan yang betul ditulis pada papan skor/hasil. Pemenangnya ditulis pada baganpertandingan.

\section{Rencana Pelaksanaan Siklus}

\section{Siklus I}

Pelaksanan setiap siklus dalam penelitian ini meliputi empat tahap sebagai berikut: 1) tahap perencanaan, 2) tahap pelaksanaan tindakan, 3) tahap pengamatan dan 4) tahap refleksi. Secara garis besar pelaksanaan tindakan tersebut dapat di deskripsikan sebagai berikut :

\section{Pelaksanaan Tindakan}

1. Kegiatan Awal

a. Memberi salam dan menanyakan keadaan siswa.

b. Guru melakukan apersepsi dengan cara menggali pengalaman siswa.

c. Menyampaikan indikator pencapaian kompetensi dan kompetensi yang diharapkan

d. Guru membagi siswa menjadi 2 kelompok secara heterogen.

\section{Kegiatan Inti}

1) Guru menyajikan ringkasan materi tentang kalimat tanya, kosa kata baku, dan keterampilan melakukan wawancara.

2) Guru menyiapkan beberapa kartu yang berisi materi yang cocok. Masing-masing siswa mendapatkan 1 kartu dan kartu yang digunakan sebanyak 45 kartu.

3) Pada siklus I, 45 kartu tersebut dibagi menjadi 3 macam tipe kartu yaitu tipe kartu berwarna kuning, hijau dan biru.

4) Siswa dibagi kedalam kelompok - kelompok kecil yang masing - masing terdiri dari 5 atau 6 orang siswa. Siswa yang memperoleh warna kartu dan kode yang sama akan tergabung dalam satu kelompok.

5) Setiap kelompok mendiskusikan materi yang diperoleh dan mengerjakan latihan soal yang ada pada kartu selama 10 menit.

6) Setiap kelompok akan mencari pasangan kartu yang sesuai selama 5 menit. Misal pada siklus I, kelompok tipe kartu berwarna kuning dengan kode 'Kuning, K.1' akan berpasangan dengan kelompok tipe kartu berwarna hijau dengan 'Hijau, H.2'. Di dalam masing-masing kartu dituliskan warna kartu dan kode yang akan menjadi pasangannya. 
7) Setiap kelompok berpasangan dengan kelompok lain yang membahas materi berbeda.Setiap kelompok saling berbagi pemahaman tentang materi dan cara pengerjaan soal-soal daftar pertanyaan. Siswa saling menanyakan, berdiskusi dan mengukuhkan jawaban sehingga didapatkan temuan baru mengenai materi dan soalsoal latihan. Masing-masing siswa merangkum hasil diskusi.

8) Guru memberi tugas kepada kelompok untuk mempresentasikan hasil diskusi. Masingmasing materi dipresentasikan oleh salah satu kelompok pembahas yang dipilih dengan cara undian.

\section{Penutup}

1. Guru bertanya jawab tentang hal-hal yang belum diketahui siswa

2. Guru bersama siswa bertanya jawab meluruskan kesalahan pemahaman, memberikan penguatan dan penyimpulan.

3. Memberikan kesimpulan.

4. Kegiatan terakhir Memberi evaluasi

\section{Tahap observasi (observing)}

Pada tahapan ini dilaksanakan observasi/pengamatan selama siklus pembelajaran berlangsung, antara lain :

1) Mengamati partisipasi dari peserta didik saat kegiatan pembelajaran siklus 1 berlangsung .

2) Mengamati kinerja guru saat melaksanaan siklus pembelajaran sesuai dengan lembar observasi yang sudah di sediakan peneliti.

3) Mencatat setiap hasil kegiatan dan perubahan yang terjadi saat pembelajaran.

\section{Tahap refleksi (reflecting)}

Setelah melaksanakan kegiatan pembelajaran pada sikus I dan melaksanakan analisis hasil pengamatan, selanjutnya mengadakan refleksi. Refleksi ini berkaitan dengan hasil belajar yang dicapai siswa setelah penggunaan metode Make a Match .Refleksi ini merupakan analisis hasil tindakan siswa mengenai seberapa jauh tingkat perubahan keaktifan belajarnya sebelum dan sesudah pelaksanaan tindakan.Kegiatan ini juga mengkaji kemampuan peneliti dalam melaksanakan tindakan. Pelaksanaan refleksi ini bertujuan untuk mempersiapkan tindakan selanjutnya yang lebih baik.

\section{Siklus II}


Pelaksanan setiap siklus II dalam penelitian ini meliputi empat tahap sebagai berikut: 1) tahap perencanaan, 2) tahap pelaksanaan tindakan, 3) tahap pengamatan dan 4) tahap refleksi. Secara garis besar pelaksanaan tindakan tersebut dapat di deskripsikan sebagai berikut :

\section{Tahap Tindakan}

1. Kegiatan Awal

2. Memberi salam dan menanyakan keadaan siswa.

3. Guru melakukan apersepsi dengan cara menggali pengalaman siswa.

4. Menyampaikan indikator pencapaian kompetensi dan kompetensi yang diharapkan

5. Guru memberikan penjelasan materi di di siklus I yang belum tuntas.

6. Guru membagi siswa menjadi 2 kelompok secara heterogen.

2. Kegiatan Inti

1. Guru menyajikan ringkasan materi tentang kalimat tanya, kosa kata baku, dan keterampilan melakukan wawancara.

2. Guru menyiapkan beberapa kartu yang berisi materi yang cocok. Masing-masing siswa mendapatkan 1 kartu dan kartu yang digunakan sebanyak 45 kartu.

3. Pada siklus I, 45 kartu tersebut dibagi menjadi 3 macam tipe kartu yaitu tipe kartu berwarna kuning, hijau dan biru.

4. Siswa dibagi kedalam kelompok - kelompok kecil yang masing - masing terdiri dari 5 atau 6 orang siswa. Siswa yang memperoleh warna kartu dan kode yang sama akan tergabung dalam satu kelompok.Setiap kelompok mendiskusikan materi yang diperoleh dan mengerjakan latihan soal yang ada pada kartu selama 10 menit.

5. Setiap kelompok akan mencari pasangan kartu yang sesuai selama 5 menit. Misal pada siklus I, kelompok tipe kartu berwarna kuning dengan kode 'Kuning, K.1' akan berpasangan dengan kelompok tipe kartu berwarna hijau dengan 'Hijau, H.2'. Di dalam masing-masing kartu dituliskan warna kartu dan kode yang akan menjadi pasangannya.

6. Setiap kelompok berpasangan dengan kelompok lain yang membahas materi berbeda.Setiap kelompok saling berbagi pemahaman tentang materi dan cara pengerjaan soal-soal daftar pertanyaan. Siswa saling menanyakan, berdiskusi dan mengukuhkan jawaban sehingga didapatkan temuan baru mengenai materi dan soalsoal latihan. Masing-masing siswa merangkum hasil diskusi. 
7. Guru memberi tugas kepada kelompok untuk mempresentasikan hasil diskusi. Masing-masing materi dipresentasikan oleh salah satu kelompok pembahas yang dipilih dengan cara undian.

\section{Penutup}

1. Guru bertanya jawab tentang hal-hal yang belum diketahui siswa

2. Guru bersama siswa bertanya jawab meluruskan kesalahan pemahaman, memberikan penguatan dan penyimpulan.

3. Memberikan kesimpulan.

4. Kegiatan terakhir Memberi evaluasi

\section{Tahap observasi (observing)}

Pada tahapan ini dilaksanakan observasi/pengamatan selama siklus pembelajaran berlangsung, antara lain :

1. Mengamati partisipasi dari peserta didik saat kegiatan pembelajaran siklus II berlangsung .

2. Mengamati kinerja guru saat melaksanaan siklus pembelajaran sesuai dengan lembar observasi yang sudah di sediakan peneliti.

3. Mencatat setiap hasil kegiatan dan perubahan yang terjadi saat pembelajaran.

\section{Tahap refleksi (reflecting)}

Setelah melaksanakan kegiatan pembelajaran pada sikus II dan melaksanakan analisis hasil pengamatan, selanjutnya mengadakan refleksi. Refleksi ini berkaitan dengan hasil belajar yang dicapai siswa setelah penggunaan metode Make a Match .pada siklus II ini biasanya memiliki perbaikan yang dilakukan di siklus 1 .

\section{HASIL DAN PEMBAHASAN}

Sesuai dengan rencana yang telah disusun, penelitian ini berlangsung selama 2 minggu dengan tatap muka sebanyak 2 kali, dengan rincian sebagai berikut:

Tabel 4.1 Jadwal Kegiatan Pelaksanaan Tindakan Penelitian Siklus I dan Siklus II

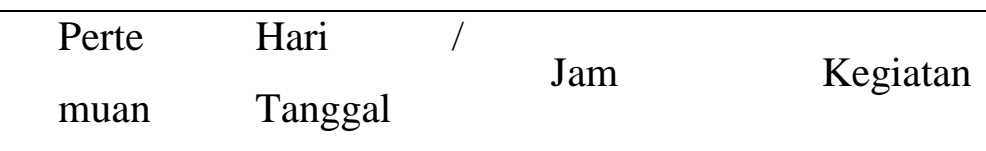




\begin{tabular}{llll}
\hline $\begin{array}{l}\text { Perte } \\
\text { muan }\end{array}$ & \multicolumn{1}{c}{$\begin{array}{c}\text { Hari } \\
\text { Tanggal }\end{array}$} & Jam & Kegiatan \\
\hline I & $\begin{array}{l}\text { senin } \\
\text { 4 April 2020 }\end{array}$ & $9.00-10.35$ & Tes pendahuluan (pre tes) \\
\hline II & $\begin{array}{l}\text { Rabu } \\
\text { 29 April 2020 }\end{array}$ & $9.00-10.35$ & $\begin{array}{l}\text { Siklus I Pertemuan I dan } \\
\text { post tes }\end{array}$ \\
\hline III & Rabu & $9.00-10.35$ & $\begin{array}{l}\text { Siklus II Pertemuan II } \\
\text { dan post tes }\end{array}$ \\
\hline
\end{tabular}

\section{Siklus I Pertemuan I}

Pada pertemuan ke -1 dilaksanakan pembelajaran kooperatif dengan teknik make a match (mencari pasangan) untuk pokok bahasan wawancara. Sebelum pembelajaran dimulai, dijelaskan langkah - langkah pembelajaran make a match (mencari pasangan) kepada siswa, selain itu disampaikan juga tujuan pembelajaran dengan pembagian 8 kelompok kerja dengan anggota kelompok 5 - 6 orang setiap kelompoknya. Guru memotivasi siswa agar saling bekerjasama dan saling membantu teman kelompoknya yang belum mengerti, guru juga memberitahu siswa untuk mencatat materi yang dipelajari pada buku catatan dan mencatat hasil pengerjaan soal - soal pada Lembar Pemantauan Jawaban (LPJ). Untuk siklus I materi yang dipelajari oleh siswa adalah kegiatan wawancara.

\section{Kegiatan kelompok}

Pembelajaran ini menggunakan media berupa kartu yang berisi soal. Guru membagikan kartu dan memberi tahu siswa untuk tidak membuka kartu sebelum anggota kelompoknya lengkap. Masing - masing soal memiliki kode tersendiri. Kartu yang memiliki kode sama, topik atau soal yang dikerjakan juga sama. Dalam setiap kartu terdapat 2 soal yang harus dikerjakan di lembar pemantauan jawaban yang sudah disediakan. Melalui kartu ini, siswa bekerjasama dan berdiskusi dengan teman kelompoknya sesuai dengan kode yang ada pada kartu. Setelah memperoleh kartu siswa mencari anggota kelompoknnya sesuai kode yang tertulis di luar kartu. Jika anggota dalam satu kelompok sudah lengkap, maka siswa membaca materi terlebih dahulu 
sesuai dengan perintah yang ada di dalam kartu, kemudian siswa bersama - sama mengerjakan soal.

Kendala yang dihadapi saat proses diskusi berlangsung yaitu terdapat kelompok yang belum berdiskusi dengan sungguh - sungguh. Tidak semua anggota mengerjakan soal, terdapat siswa yang bergurau dengan teman kelompoknya bahkan ada yang bergurau dengan anggota kelompok yang lain. Hal ini menyebabkan kondisi kelas ramai dan anggota kelompok yang lain terganggu. Selain itu, terdapat siswa yang tidak mau berdiskusi dengan anggota kelompoknya karena siswa tersebut merasa canggung dan malu terhadap temannya. Pada akhirnya siswa mengerjakan soal sendiri dan menghindar dari teman satu kelompoknya.

Waktu yang diberikan untuk pengerjaan soal pada kelompok awal adalah 10 menit.Setelah waktu selesai, maka siswa mencari kelompok pasangannya sesuai dengan kode yang ada di dalam kartu. Kemudian dua kelompok tersebut saling bertukar kartu untuk mengerjakan soal dari kelompok pasangan yang baru.Soal dari kelompok baru ini dikerjakan secara berkelompok yaitu sesuai kelompok awal.Jika kedua kelompok telah selesai mengerjakan soal, kemudian secara bergantian perwakilan masing - masing kelompok meminta jawaban dari kelompok baru untuk menyebutkan jawaban dari soal yang dikerjakan.Hasil dari mencocokkan jawaban dicatat di lembar pemantauan jawaban.

Siswa tidak hanya mengerjakan 2 soal yang berbeda, tetapi siswa diberi kesempatan sebanyak 4 kali untuk mengerjakan soal yang berbeda dari kelompok lain dengan syarat warna atau kode kartu harus berbeda dari masing - masing soal. Hasil diskusi yang diperoleh siswa pada siklus I yaitu siswa mampu menyelesaikan soal - soal berkaitan dengan tahapan wawancara. Siswa tidak hanya mengerjakan 1 soal saja tetapi siswa bisa mengerjakan 3 soal. Ketika siswa bertukar kartu dengan kelompok lain, siswa mengerjakan soal dari kelompok lain yang memiliki materi yang sama dengan soal yang berbeda-beda di setiap kelompok.

\section{Penutup}

Guru bersama siswa menyimpulkan materi wawancara yang meliputi persiapan wawancara, tahapan wawancara dan menulis hasil wawancara. Guru menginformasikan bahwa pertemuan berikutnya akan diadakan sesi presentasi. Guru juga meminta siswa untuk mempelajari seluruh materi wawancara yang sudah dipelajari hari ini dan menginformasikan bahwa 15 menit sebelum akhir pembelajaran pertemuan berikutnya akan diadakan tes akhir. 
Dari hasil pengamatan diperoleh data hasil belajar siswa pada siklus 1 sebagai berikut.

\begin{tabular}{|c|c|c|c|}
\hline No & Nama siswa & Nilai & Ketuntasan belajar \\
\hline 1 & Aminatus sakdiyah & 50 & Tidak Tuntas \\
\hline 2 & Zahira prisilia & 60 & Tidak Tuntas \\
\hline 3 & Nandita & 50 & Tidak Tuntas \\
\hline 4 & Riko hasan & 85 & Tuntas \\
\hline 5 & Moh. Nino ardian & 80 & Tuntas \\
\hline 6 & Ferdi tanto & 60 & Tidak Tuntas \\
\hline 7 & Medina aprilia & 75 & Tuntas \\
\hline 8 & Nenti aulia putri & 60 & Tidak Tuntas \\
\hline 9 & Yoga firmansyah & 85 & Tuntas \\
\hline 10 & Ilham baihaqi & 80 & Tuntas \\
\hline 11 & Kiki alfiansyah & 60 & Tidak Tuntas \\
\hline 12 & Tio hermantoi & 78 & Tuntas \\
\hline 13 & Setia pratiwi & 75 & Tuntas \\
\hline 14 & Meita azzahra & 80 & Tuntas \\
\hline 15 & Nindi kumalasari & 75 & Tuntas \\
\hline
\end{tabular}

Tabel 4.1.2 Tabel Hasil belajar siswa pada kegiatan siklus 1

Hasil belajar siswa setelah proses pembelajaran siklus I terdapat pada lampiran secara ringkas seperti Tabel 4.2 berikut ini.

Tabel 4.1.2 Hasil Belajar Siswa Pada Siklus I

\begin{tabular}{|l|c|c|}
\hline Perolehan Nilai & $\begin{array}{c}\text { Jumlah } \\
\text { Siswa }\end{array}$ & Persentase (\%) \\
\hline Tuntas $(\geq 70)$ & 9 & $60 \%$ \\
\hline Belum Tuntas $(<70)$ & 6 & $40 \%$ \\
\hline Jumlah & 15 & $100 \%$ \\
\hline
\end{tabular}

(Sumber: data yang diolah)

Adapun Hasil belajar siswa yang diperoleh saat post test pada siklus 1 rata-rata nilai sebesar $\geq 70$ dan $60 \%$ yang mencapai KKM. Jumlah siswa di kelas IV terdapat 15 
anak, 9 siswa yang tuntas dalam pembelajaran dengan skor $60 \%$ dan 6 siswa tidak tuntas dengan skor $40 \%$.

Adapun grafik prosentasenya sebagai berikut :

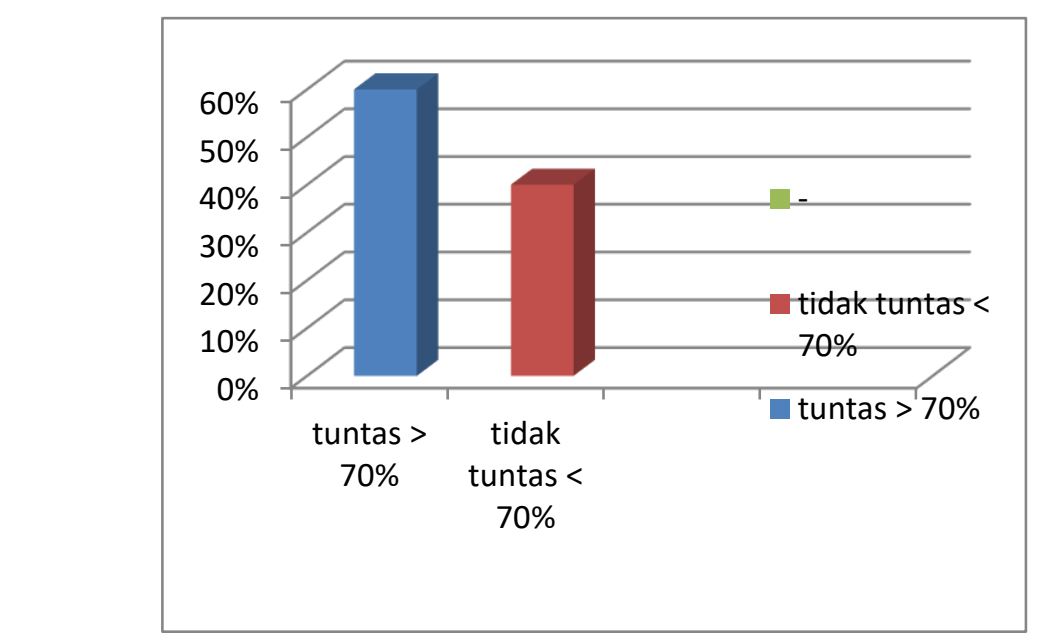

\section{KESIMPULAN}

Berdasarkan hasil penelitian dan pembahasan yang telah diuraikan, maka dapat diambil kesimpulan sebagai berikut: Penerapan pembelajaran kooperatif dengan teknik make a match (mencari pasangan) pada sub pokok bahasan pemfaktoran suku aljabar pada penelitian ini diawali dengan tahap pendahuluan yaitu guru membuka pelajaran dan menjelaskan langkah langkah pelaksanaan pembelajaran kooperatif dengan teknik make a match (mencari pasangan). Tahap selanjutnya yaitu kegiatan kelompok dimana siswa melaksanakan diskusi dengan kelompok awal dan dilanjutkan dengan kelompok baru. Tahap yang terakhir yaitu formalisasi dimana siswa mempresentasikan hasil diskusi kelompok di depan kelas. Setelah pertemuan pada siklus I, masing - masing siswa diberikan post tes secara individual. Pembelajaran ini berlangsung 2 siklus, yakni pembelajaran pada siklus I serta pembelajaran pada siklus II dimana keduanya memiliki kesamaan dalam metode maupun dalam materi pembelajaran. Siklus I berlangsung sesuai dengan apa yang direncanakan, dengan ketuntasan belajar klasikal siswa $\geq$ 70\%. Hasil belajar siswa yang diperoleh dari siklus 1 yaitu dari 15 siswa hanya 9 siswa yang tuntas dengan prosentase $60 \%$ dan yang tidak tuntas hasil belajarnya 6 siswa dengan prosentasi $40 \%$. Revisi perencanaan dilakukan setelah siklus I dilakukan dengan mengurangi jumlah siswa dalam satu kelompok. Jumlah siswa dalam satu kelompok awal pada siklus I adalah 5 - 6 orang pada siklus II dalam satu kelompok awal terdapat 2 orang siswa. Tindakan lain dalam revisi perencanaan yaitu mengurangi jumlah soal pada kartu dimana jumlah soal yang harus dikerjakan dalam 1 kelompok pada siklus I adalah 2 soal sedangkan siklus II hanya 1 soal, serta menambah 
frekuensi bagi siswa untuk mengerjakan soal yang berbeda. maka Siklus II berlangsung dengan baik dengan perolehan angka ketuntasan $>70 \%$ dari 15 siswa ada 13 siswa yang tuntas dengan prosentase $86,67 \%$ dan 2 siswa yang tidak tuntas dengan prosentase nilai 13,33\%. Sehingga bisa kita simpulkan bahwa dengan menggunakan model pembelajaran Make A Match dapat meningkatkan hasil belajar siswa pada kelas IV di SDN 5 Olean.

\section{DAFTAR PUSTAKA}

Hamalik, O. 2005.Proses Belajar Mengajar. Bandung: Bumi Aksara

Isjoni. 2010. Cooperative Learning Efektifitas Pembelajaran Kelompok. Alfabeta. Bandung Purwaning Galih dan Darisman. 2015. Bahasa Indonesia, Yudistira. Bogor

Suharsimi Arikunto dkk. 2009. Penelitian Tindakan Kelas. PT. Bumi Aksara. Jakarta

Lie, A. 2004. Cooperatif Learning (Mempraktekkan Cooperatif Learning Di ruang-Ruang Kelas). Jakarta:Grasindo

Slameto.2003. Belajar Dan Faktor-faktor Yang Mempengaruhinya. Jakarta: Rineka Cipta

Sardirman. 1991. Ilmu Pendidikan. Bandung : Remaja Rosdakarya. 